\title{
Cultural Identity: The Era of Chinese Martial Arts Inheritance and Development
}

\author{
Kun Liü, 2, a, Na Liu', b \\ ${ }^{1}$ PE Department of Soochow University, Suzhou 215021 China; \\ 2PE Department of Jiangxi University of Traditional Chinese Medicine, Nanchang 330004 China. \\ aliuk0791@163.com, b329022334@qq.com
}

\begin{abstract}
This article USES the literature material law, discusses the development of Chinese martial arts from the perspective of cultural identity crisis dilemma of internal cause and external cause. Study suggests: modern squeezes the space of contemporary Chinese martial arts culture led to the fracture of the Chinese martial arts culture of traditional ties, make Chinese wushu culture identity began to blur, split, then create the cultural identity crisis, its basic reason is that the introduction of western troops operating in the westernization movement in modern China and later the "soil foreign sports dispute" people of the martial arts in the concept of identity.
\end{abstract}

Keywords: Cultural identity; Chinese martial arts; development.

\section{Introduction}

"Of the Chinese nation has five thousand years of history of civilization, the Chinese culture with the deep spiritual pursuit of the Chinese nation, gene contains the fundamental spirit of the Chinese nation, represent the unique spiritual symbol of the Chinese nation, is a perennial, development of the Chinese nation's rich nourishing" [1] but, "since modern times, China has been plagued by" westernization ", traditional culture is facing crisis, cultural crisis lead to people lose 'cultural character, also lost the root of the nation."[2]Chinese martial arts is a part of Chinese culture, the spirit and value of it is blowin 'in the western context. Therefore, respect for tradition, a return to traditional culture has become the inevitable choice. Because "[3] for any national culture is the root of it. The development of the ethnic culture is a natural link, it based on consanguinity and geography, the total of the spirit and character of a nation together." And "cultural identity" is the best way to this choice (return) of Chinese wushu.

\section{The Concept of Cultural Identity}

"Identity" as a general rule, identity is refers to "to confirm or the same things together."[4] It exists in a relationship, it refers to the people and the relationship between people and society, the people and groups. Including cognitive, trust and commitment. Cognitive self-centered, for example, "who am I?""I come from?" "Where is my home?" All belong to the category of identity. Identification of types including ethnic identity, national identity, social identity, identity (group), age, identity and professional identity, gender identity, and a variety of types such as cultural identity, cultural identity as the core in many types of identity types. Because of other types of identity all contain the factors of cultural identity. Culture, is the essence of the distinction between humans and other species. Cultural identity, including social value standard identity, religious identity, view of customs acquisition, identification, art ".

\section{The Context of Modern Era of Chinese Martial Arts Culture Identity Dilemma, Lost and Roots}

\subsection{Modern Martial Arts Culture Space are Squeezed.}

"Cultural space" also known as the "cultural sites" (Culture Place), is the United Nations educational, scientific and cultural organization in the protection of intangible cultural heritage is a proper noun, refers to the human oral and non-material heritage representative work of form and style. 
"Published in 1989, the United Nations educational, scientific and cultural organization announced regulations on the human oral and non-material heritage representative work, points out that cultural space" for a centralized location of folk and traditional cultural activities, but also in general are identified as a cycle, cycle, season, calendar, etc.) or incident marked a period of time [5]"In 2002, UNESCO officials edmond wood carra said:" refers to a folk cultural space or a concentration of activities in the traditional culture, or to a particular, regular cultural events of the selected time".[6]Our country in 2005, the general office of the state council issued "the national intangible cultural heritage representative work evaluation interim measures for the declaration, which points out that" cultural space, namely the traditional cultural activities held regularly or a showcase of place traditional culture form, both space and timeliness."[7]

Huge changes to the way the modern social production, the breakthrough the original frame of traditional society, make people's life style and the way of communication from the early occlusion to modern open, from the original stability to change, from the initial order to messy. Modern way of and pace disrupted the original ecological natural pace of Chinese wushu culture. In the past, rooted in the farming civilization of Chinese martial arts in the modern era of rapid development makes its original cultural space more serious extrusion, is facing the survival test. Especially the 30 years of urbanization of China's reform, intensify the atrophy of the martial arts living space. Embodied martial arts culture of traditional village, temple fairs, festivals and celebration of "cultural space" display of traditional culture is slowly lost.

\subsection{The Introduction of Western Soldiers Hold to "Foreign Sports Dispute".}

Eyes "open world" put forward by the Lin zexu and wei yuan's "long skill with barbarians" and so on, they all have a common goal: the Chinese must learn the west. As a result, the westernization movement entered the stage of history. Westernization movement first is the introduction of western modern army soldiers hold, "mainly practice German soldiers hold, German soldiers fuck content mainly includes the individual coaching and queue formation, also practice sheets, the parallel bars, the trojans, platforms and other instrument gymnastics", ${ }^{[8]}$ from here we can see that the practice of project is indeed western sports gymnastics teaching content, today, the content is still the main content of gymnastics teaching in the school sports in China. Soldiers hold "is actually a military school introduced PE".

From the initial gymnastics to the later school of martial arts, the Chinese people have Chinese martial arts and western physical draw an equal sign. If soldiers hold introduction is on the understanding of western sports have a hazy thoughts, then from the domestic most influential sports organizations, the change of the name "jingwuyangxiong sports club" as you can see how Chinese martial arts and western physical intertwined.

This, however, is only the prelude to a "soil foreign sports". Really was in the 1930 s China sprinter, the failure of the Olympic Games in Los Angeles in 1932, triggered the sports in China was a fierce debate "soil foreign sports". Its focus is when China is to advocate western sports in the form of "foreign sports", or advocate martial arts as the main form of "sports". Foreign sports dispute "the" soil as the Japanese imperialist war of aggression against China upgrade gradually turned into "sports saving theory", "national TiYuHua" and "sports militarization" of the debate. "Soil foreign sports" is the result of the martial arts to "surrender". The influence of western sports in martial arts is "absolute overborne", the relationship between them become the "obedience and be obeyed" relationship.

\section{In the Modern Reflection Way to Explore the Cultural Identity of Chinese Wushu}

\subsection{To Improve the Cultural Tension of the Chinese Martial Arts, to Grasp the Discourse.}

In today's modernization and globalization, the world is in an era of cultural diversity development. Relative to the local culture and foreign culture is generally referred to as the different culture, local culture general exclusion and comparing the performance of the different culture, but also have alienated. Relative to the western culture, the conclusion of "soil foreign sports dispute" whether "Chinese-style westernization" "west body with" or "wholesale westernization" and so on, we treat different culture must keep a clear head, because of the different culture is objective existence, it is 
not as people's will and transfer. We need to identify with the different culture, for treatment of vision culture, cannot obtain the approval, it will be difficult to accept; Can only be identified with the different culture to accept different culture, for the development of the different cultural identity is often get the premise.

Treat different cultural identity, of course, not to their own culture negative, on the contrary, is a sign of its own cultural identity. The development of Chinese martial arts to improve their own key is esteemed coordinating the relationship between the martial arts culture and the western sports culture, keep a certain tension in the identity. It must be admitted that modernization brought certain impact to Chinese martial arts, we need to in the wushu inheritance and the construction of cultural integration. Such integration is based on Chinese martial arts as the main body, the western sports culture composition structure and absorption.

\subsection{Cultural Consciousness and Cultural Confidence - cultural needs of the People.}

The current Chinese culture, which constantly in the process of modernization, the loss of a dominant position. Mu said: "our country in recent decades to destroy all the hardship, the biggest reason, is for the people to lose confidence, self-respect, their cultural traditions look too light, or even to produce a kind of contempt and rejection of one's own culture psychology", when we looked around, the inside of the city taekwondo hall, judo, boxing gym, yoga, such as have sprung up, people rush to chung sports to study abroad, even to the point of worship. We have to transfer this kind of situation, to promote the modernization development of wushu culture, make people really realize the essence of martial arts. We need to get the intrinsic value of the martial arts culture connotation, the core is not to determine again, but the system of mining and sorting out, to show. Upon confirmation of the martial arts and cultural value and connotation of self-knowledge, and fully confident the formation of the culture. We must know fully the circumstances to do cultural confidence in myself.

\section{Conclusion}

Extensive and profound Chinese wushu culture, it is our the status symbol of the Chinese nation. The cultural pattern of diversity in the development of the integration of the world is, vigorously carry forward the traditional culture is the first step of us to achieve the Chinese dream. In order to realize China's dream must carry forward the spirit of China, we would do well to inheritance and carry forward the traditional culture, to clear the historical origin and development of Chinese excellent culture context, the basic direction, clear the unique Chinese culture creation, value concept, characteristics, strengthen the cultural confidence and values. In the country to vigorously develop the cultural soft power and achieve the great rejuvenation of the Chinese nation under the background of the Chinese dream, we must stand in the height of the countries to develop Chinese wushu culture, only in this way, Chinese martial arts to have a more broad space for development.

\section{References}

[1] propaganda department of the central committee of the communist party of China [M]. Xi jinping, general secretary of the series of important speech reader, Beijing: people's publishing house, 2014.6:100

Practice chung chao

[2] Lian congchao ,Look from the phenomenon of "blue and white porcelain" Chinese cultural regression and cultural identity [J]. Journal of jiangxi social science, 2014 (2): 235-237

[3] Qiedong. The big crisis [M]. Beijing: China friendship publishing company, 2006:126.

[4] Cui xingjian. Cultural identity and its root [J]. Journal of Beijing normal university (social science edition), 2004 (4): 102-104

[5] Wang wen-zhang. An introduction to intangible cultural heritage [M]. Beijing: culture and art publishing house, 2006.412 
[6] Edmund wood Carla. Oral and non-material heritage representative work summary [A]. Rescue and protection of human oral and non-material heritage international conference [C]. Beijing: China academy of art, 2002.65

[7] Wang wen-zhang An introduction to intangible cultural heritage [M]. Beijing: culture and art publishing house, 2006:412

[8] Luo Shiming. China's modern sports interpretation of cultural change [M]. Beijing: Beijing sport university press, $2007,1: 15$ to 17 